\title{
多自由度ダンパ要素を付加したボーリングバーの 防振設計の研究*
}

吉 村允 孝** 土肥嘉夫*** 広 瀬啓二十

Study on Vibration-proof Design of Boring Bar with Multiple

Degree-of-Freedom Dampers

Masataka Yoshimura, Yoshio DoHi and Keiji Hirose

In order to increase stability against machining chatter in boring operations, boring bars equipped with multiple degree-of-freedom dampers have been developed. By using the dampers, the modal flexibility at the natural mode having the greatest receptance is divided into smaller modal flexibilities at multiple degrees of natural modes. This theoretical analysis clarifies that the division of the modal flexibility into many natural modes results in 1) the decrease of the modal flexibility, 2) the increase of the damping ratio, and 3) shift of the vector locus of the receptance frequency response along the real axis toward the positive direction. These changes occur at the natural mode having the greatest modal flexibility, producing a great increase in stability against the machining chatter. Design procedures for the boring bars are described, and the effect of the dampers is demonstrated in actual cutting tests.

Key words : boring bar, damper, machine tool, dynamic characteristics, regenerative chatter, machining chatter, modal flexibility, damping ratio, frequency response

\section{1. 緒論}

中ぐり加工に用いられるボーリングバイトは動的な 剛性が必然的に低く，びびり振動の発生を抑觉ること が困難なことが多い.このため種々のダンパを付加し たボーリングバーが提案され(1) 3), 既に実用に供せら れているものもある。しかし現在でもその決め手とな るものが存在せず，ボーリングバイトによる深穴加工 の切削能率と加工精度を上げることは困難とされてい る.

本研究では, ボーリングバイトのびびり振動に対す る安定性を向上させるために, びびり振動発生の原因 となる固有モードのモーダルフレキシビリティ'を, 多くの固有モードのモーダルフレキシビリティに人為 的に分割させる多自由度ダンパ要素を付加した防振 ボーリングバーを提唱する。

以下，まずこれまでのボーリングバーの防振対策に ついて考察する。そしてその考察から得られた問題点

* 原稿受付 昭和 59 年 3 月 22 日. 昭和 57 年度精機学会秋 季大会学術講演会（昭和 57 年 10 月 18 日）にて発表

** 正 会 員 京都大学工学部 (京都市左京区吉田本町)

*** 正会 員 住友電気工業(株)（伊丹市昆陽字宮東 1)

†正会員 住友電気工業(株) (名古屋市南区新郊通 1-10)
をふま光た上で提唱するボーリングバーの理論的考察 と設計法を述べ，最後に試作例を示す。

以下の用語の中で, “直接”という語が頭についてい るものは力が加わる点と方向が変位を求める点と方向 に一致する場合に用い, “交差”はそれらが一致しない 場合に用いる。

\section{2. ボーリングバーの防振設計についての考察}

图 1 は工作機械に取り付けられたボーリングバーの 様子を模擬的に示している。この切削点におけるリ七 プタンス周波数応答は, 図 2 (a)のようになる。すなわ ちボーリングバーの軸径が細く, また突出し長さ $L_{t}$ が長くなると, 静コンプライアンス $f_{s}$ が大きくなると

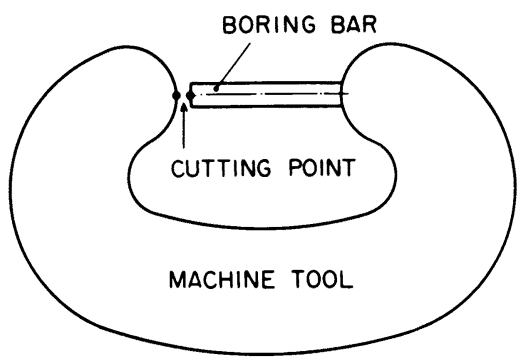

Fig. 1 A conceptual model of a machine-tool structural system having a boring bar 


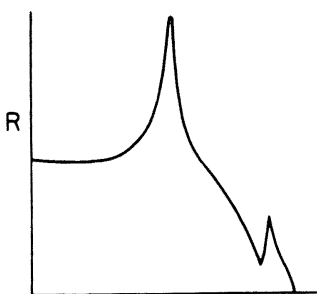

(a)

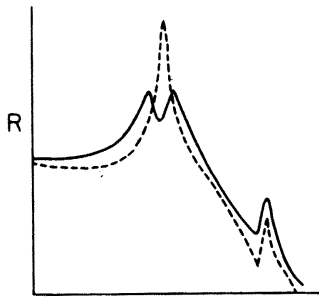

(c)

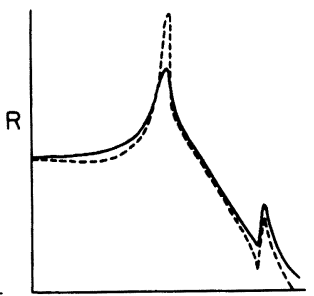

(b)

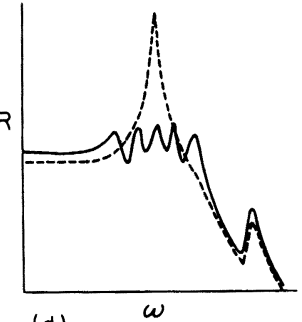

(d)
Fig. 2 Receptance frequency responses

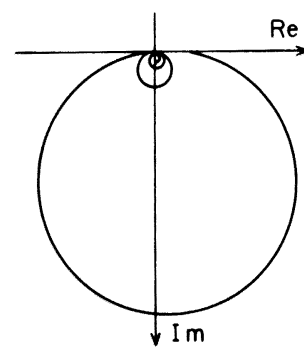

(a)

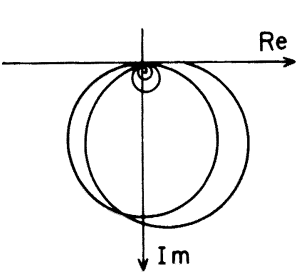

(c)

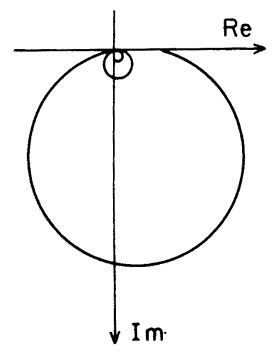

(b)

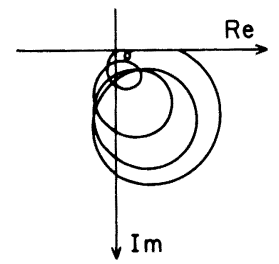

(d)
Fig. 3 Vector loci receptance frequency responses corresponding to bode diagrams shown in Fig. 2

ともに, ある固有モードのリセプタンス値 $R$ が非常に 大きくなる。このリセプタンス周波数応答をべクトル 軌跡上に描くと, 図 3 (a) のように, ベクトル軌跡上の 最大負実部の大きさも大きくなる。このことは，再生 型自励びびりが非常に発生しやすい状態を意味してい る。

この切削点に括ける切削力方向の加振力 $F$ と切削 面に垂直な方向の変位 $D$ (工具と品物の間の相対変 位）に関するリセプタンス周波数応答の角振動数 $\omega$ に おける伝達関数表示式は，比例减衰系としての近似の もとで, 次式のように書かれる。

$$
R(\omega)=\frac{D}{F}(\omega)=\sum_{m=1}^{\infty}\left[\frac{f_{m}}{1-\left(\frac{\omega}{\omega_{m}}\right)^{2}+2 \mathrm{j}\left(\frac{\omega}{\omega_{m}}\right) \zeta_{m}}\right]
$$

ここで, $\mathrm{j}$ は虚数単位, そして $\omega_{m}$ と $\zeta_{m}$ は $m$ 次固有 モ一ドの固有角振動数と減衰比である. また $f_{m}$ は, $m$ 次固有モードに打ける切削点の切削力方向と切削面に 垂直方向の間の交差モーダルフレキシビリティであ る.

通常, ボーリングバーの部分は, 工作機械本体に比 してはるかに剛性が低い，そのためびびり振動が問題 となる固有モードに拧いては，ボーリングバーのみで ほとんど振動系を形成し，工作機械本体の影響が非常 に小さくなる。しかもボーリングバーは軸対称構造で ある。これらのことより, 力が加わる方向と変位を求 める方向が一致しないために一般には負の值をもちう る交差モーダルフレキシビリティは，すべて正の值を もつとみなせる，以下，この交差モーダルフレキシビ リティを略記して，モーダルフレキシビリティとする。

式（1）に $\omega=0$ を代入することによりわかるよう に, 切削点での静コンプライアンス $f_{s}$ と $m$ 次固有 モードのモーダルフレキシビリティ $f_{m}$ の間には, 次 の関係がある。

$$
f_{s}=\sum_{m=1}^{\infty} f_{m}
$$

いま $i$ 次固有モードのリセプタンス值 $R_{i}$ が非常に大 きいとする，そのとき，その固有モードのモーダルフ レキシビリティ $f_{i}$ も大きく，次のように表せる。

$$
f_{s}=f_{i}+\sum_{\substack{m=1 \\ m \neq i}}^{\infty} f_{m} \fallingdotseq f_{i}
$$

再生型自励びびりに対する安定性を増すには, リセ プタンス值 $R_{i}$ を小さくすることが必要である。 その ためには，モーダルフレキシビリティ $f_{i}$ をさくする ことと，減衰比 $\zeta_{i}$ を大さくすることが要求される。 こ の要求を満たすことがボーリングバーの防振設計の目 的であり，以下のようないろいろな方法が存在する。

（1）ボーリングバーの材料として超硬などの高剛 性材料を用いる。高剛性材料として超硬を用いる と，鋼に比して約 3 倍の縦弾性係数の分だけ静コ ンプライアンス $f_{s}$ が下がり，モーダルフレキシビ リティ $f_{i}$ の減少となる。しかし, 実際には, ボー リングバー支持部などの剛性が影響し, 綐弾性係 数の増大分だけの剛性の上昇が望めないことがあ る.

（2）減衰能力をもつ要素を付加する。これは減衰比 
$\zeta_{i}$ を大きくとることによって,リセプタンス值 $R_{i}$ を小さくしょらとするものである。ボーリング バーの内部に減衰材料を挿入したり, インパクト ダンパのように衝撃により振動エネルギーを吸収 する方法がこれに属する。図 2 (b) と図 3 (b) は, この場合のリセプタンス周波数応答の例示であ る。しかし，減衰比の上昇には限度があり，十分 にリセプタンス値を下げられないことがある.

（3）ダイナミックダンパ要素を付加する。これは 1 自由度要素をもとの振動系に付加することによっ て，モーダルフレキシビリティ $f_{i}$ をつの固有 モードのモーダルフレキシビリティ $f_{i 1}$ と $f_{i 2}$ に 分割していると解釈できる。すなわち,

$$
f_{s}=f_{i 1}+f_{i 2}+\sum_{\substack{m=1 \\ m \neq i}}^{\infty} f_{m} \fallingdotseq f_{i 1}+f_{i 2}
$$

と表せ, モーダルフレキシビリティの最大值を半 減しうる.しか子固有モード $i 1$ と $i 2$ における減 衰比を油や高分子材料などの減衰作用により高め ている. 図 2 (c) と図 3 (c) は, この場合のリセプ タンス周波数応答の例示である。

上記 (1)，(2)，(3) の方法により，それぞれ最大とな るリセプタンス值を減少でき, 程度の差はあるが, び びり振動に対する安定性を増す上で効果がある。しか し，それでも不十分なことが多いのが現状である，防 振設計の立場から，ボーリングバーの望ましい特性と して次のことがあげられる。

（a）リセプタンス值が最も大きい固有モードの モーダルフレキシビリティをできる限り小さくす る.

（b）リセプタンス值が大きい固有モードの減衰比 を大きくする。

（c）リセプタンス周波数応答のベクトル軌跡にお ける最大負実部の大きさを小さくするために，リ セプタンス值の大きい固有モードのベクトル軌跡 を正実部方向へ移動させる.

（d）設計変数の徽少な変化に対する特性の感度 を，できるだけ小さくする。

\section{3. 多自由度タンパ要素付加による防振設計の理論}

\section{1 モーダルフレキシビリティの分割によるモー タルフレキシビリティの最大值の滅少}

本研究で提唱するボーリングバーの防振設計の基本 概念は，最も大きな值をもつモーダルフレキシビリ ティ $f_{i}$ を 3 つ上 $N$ 個の固有モードのモーダルフレ キシビリティに分割させることにより，モーダルフレ キシビリティの最大值を減少させることにある. 式の

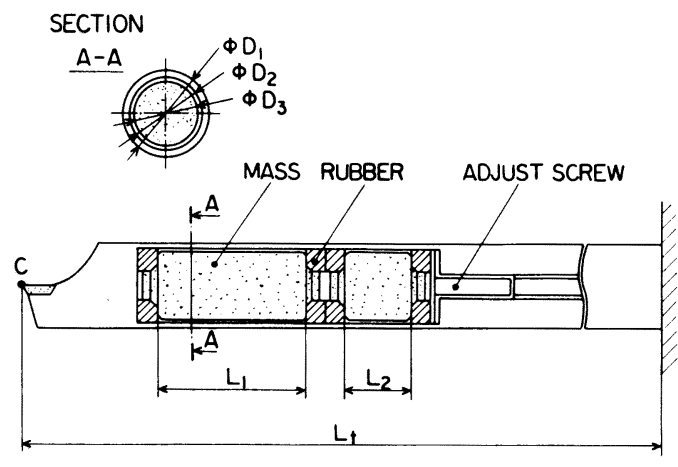

(a) A boring bar with two mass elements

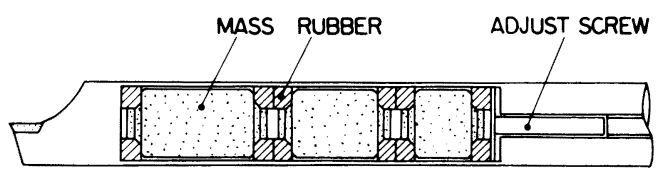

(b) A boring bar with three mass elements

Fig. 4 Inside features of boring bars equipped with damper elements

上では，次のように表さ侊る。

$$
f_{s}=\sum_{j=1}^{N} f_{i j}+\sum_{\substack{m=1 \\ m \neq i}}^{\infty} f_{m} \fallingdotseq \sum_{j=1}^{N} f_{i j}
$$

このとき, 静コンプライアンス $f_{s}$ は, 付加要素のあり なしにかかわらず一定である.

モーダルフレキシビリティ $f_{i} を N$ 個の固有モード のモーダルフレキシビリティに分割するには， $i$ 次固 有振動数付近に固有振動数をもつ $N-1$ 以上の自由 度をもつ要素を元の振動系に付加する必要がある，図 4 (a) および (b) は，付加要素として2 質量要素およ び 3 質量要素を装備したボーリングバー内部の様子を 示している，各質量要素の両端は，耐油性のゴムで支 えられている。ばね要素としての働きをするゴムに よって両端を支えられた 1 つの質量要素は，2 自由度 の力学的自由度をもっている。 したがって, 付加質量 要素が 1 個, 2 個, 3 個の各場合は, 元のボーリングバー に 2 自由度, 4 自由度, 6 自由度の要素を付加すること

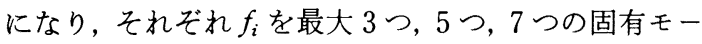
ドにわたって分割することができる。これらの付加要 素の設計変数を選択することにより，モーダルフレキ シビリティ值 $f_{i j}(j=1,2, \cdots, N)$ の大きさ，それぞれ に対応するリセプタンス值 $R_{i j}(j=1,2, \cdots, N)$ の大 きさを調整することができる.

付加要素の質量および慣性質量は，大きいほど設計 変数の微少な変化が性能に及ぼす感度が鈍く,ボーリ ングバーの実用上有利である゙（このことは，付加要素 の質量および慣性質量が小さいほど $N$ 個の固有モ一 ド相互の固有振動数差が小さくなり, 設計変数の微少 
な変化に対するモーダルフレキシビリティと減衰比の 感度係数 ${ }^{6)}$ が大きくなることからも理解しらる).した がって, 図 4 (a), (b) に示されるように, 許される空間 内にできるだけ大きな体積をもつ要素を挿入するよう 設計すると同時に，超硬や超重合金のよらな大きな密 度をもつ材料を用いることが必要である。

\section{2 隇衰比の増大}

$i$ 次固有モードでの定常振動状態において, ボーリ ングバー本体とその固定部に蓄えられる復元エネル ギー量を $V_{B i}$, 付加質量の支持要素 (ばね要素) に蓄え られる復元ェネルギー量を $V_{R i}$, そしてそれらの全体 で蓄えられる復元ェネルギー量を $V_{T i}$ とすると, 次式 のように表せる。

$$
V_{T i}=V_{B i}+V_{R i}
$$

このときの切削点 $\mathrm{C}$ での変位を $D_{C}$ とすれば，ボーリ ングバー本体とその固定部からなる構造の等価ばね剛 性 $k_{B}$ は $1 / f_{S}$ で近似できることより， $V_{B i}$ は次式のよ らに得られる。

$$
V_{B i}=\frac{1}{2} k_{B} D_{C}^{2}=\frac{1}{2} \frac{D_{c}^{2}}{f_{s}}
$$

切削点におけるモーダルフレキシビリティ $f_{i}$ は,

$$
\frac{D_{C}^{2}}{2 V_{T i}}=f_{i}
$$

として求められることより, 式 $(6),(7),(8)$ を整理す れば，次式が得られる。

$$
\frac{V_{R i}}{V_{T i}}=1-\frac{f_{i}}{f_{s}}
$$

上式より， $f_{i} / f_{s}$ が小さければ，付加質量の支持要素で の復元ェネルギーの分布率が大きいことがわかる.

$i$ 次固有モードの減衰比 $\zeta_{i}$ は, $V_{B i}, V_{R i}, V_{T i}$ に対応 する部分の 1 周期当たりの減衰エネルギー量 $D_{B i}$, $D_{R i}, D_{T i}$ を用いて, 次式として求められる.

$$
\zeta_{i}=\frac{D_{T i}}{4 \pi V_{T i}}=\frac{V_{B i}}{V_{T i}} \frac{D_{B i}}{4 \pi V_{B i}}+\frac{V_{R i}}{V_{T i}} \frac{D_{R i}}{4 \pi V_{R i}}
$$

付加質量の支持要素はゴムであり, その部分の等価減 衰比 $\zeta_{R}$ すなわち $D_{R i} / 4 \pi V_{R i}$ は, ボーリングバー本体 の等価減衰比 $\zeta_{B}$ すなわち $D_{B i} / 4 \pi V_{B i}$ よりはるかに大 きい. $f_{i} / f_{s}$ が小さくなり, 式 (9) の関係式より $V_{R i} /$ $V_{T i}$ が大きくなれば, $i$ 次固有モードの減衰比 $\zeta_{i}$ が増 大することになる。

したがって静コンプライアンス $f_{s}$ 多数の固有 モードのモーダルフレキシビリティに分割し，モーダ ルフレキシビリティの静コンプライアンスに対する比 の最大值を小さくすれば，モーダルフレキシビリティ の最大值の減少ばかりでなく，その固有モードの減衰 比の増大につながることが証明される。

\section{3 ベクトル軌跡の安定側への移動}

$i$ 次固有モードのリセプタンス周波数応答のベクト ル軌跡が，ほかの固有モードの影響を受けて央軸上を 正の方向へ移動する量 $G_{i}$ は, 次式のように定まる7).

$$
G_{i}=-\sum_{p=1}^{i-1} f_{p}\left(\frac{\omega_{p}}{\omega_{i}}\right)^{2}+\sum_{q=i+1}^{\infty} f_{q}
$$

ここで， $\omega_{i}$ と $\omega_{p}$ は， $i$ 次および $p$ 次の固有モ一ドの 角固有振動数, $f_{p}$ と $f_{q}$ は $p$ 次拈よび $q$ 次の固有モード のモーダルフレキシビリティである. $G_{i}$ が大きいため には, $i+1$ 次以後の固有モードのモーダルフレキシビ リティの和が大きく, そして $i-1$ 次以前の固有モード のモーダルフレキシビリティが小さいか, あるいは大 きい固有モードが存在してもその固有モードの固有振 動数が $i$ 次の固有振動数から十分に離れていることが 必要である。

問題となる大きなモーダルフレキシビリティをもつ $i$ 次の固有モードのベクトル軌跡を, びびり振動に対 して安定側の正実部方向へ移動させるのは, $i+1$ 次以 上の固有モードのモーダルフレキシビリティの和であ ることより，概念的には静コンプライアンスをできる だけ多くの固有モードのモーダルフレキシビリティに 均等に分割させることが要求される。このことは, 3.1 節で述べた処置によって㬰現しうることがわかる.

以上の $3.1 ， 3.2,3.3$ 節の事柄はすべて，ボーリン グバーの再生型自励びびりに対する安定性の向上につ ながる.この防振ボーリングバーでは, リセプタンス 周波数応答のボード線図が図 2 (d) のようにそして そのベクトル軌跡が図 3 (d) のようになる.

\section{4. 設計変数の決定法}

図 5 (a) および (b) は, 図 4(a)および (b) の防振 ボーリングバーの構造解析のための数学モデルを示し ている.ボーリングバーの本体および付加質量要素は, はり要素で，そして付加質量要素支持のためのゴム要 素はボーリングバーの軸に垂直方向のばねとダンパの

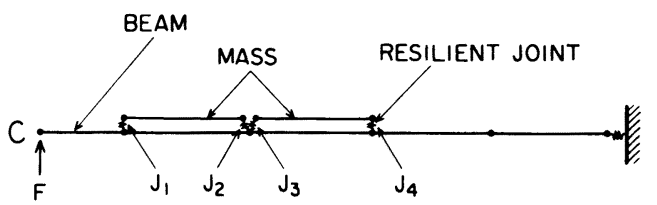

(a) A boring bar with two mass elements

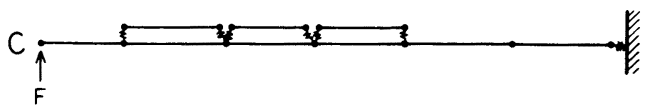

(b) A boring bar with three mass elements

Fig. 5 Models for the structural analysis of the boring bars 
並列要素でモデル化している。またボーリングバーの 固定端は，6つの座標方向のばねとダンパの並列要素 でモデル化している. 図中, 黒丸は構造解析のための 節点を表す。

この設計問題に打ける設計変数は，ボーリングバー 本体の軸外径 $D_{1}$ と内径 $D_{2}$, 付加質量要素の数 $M$ と 径 $D_{3}$, 付加質量要素の長さ $L_{j}(j=1,2, \cdots, M)$, 付 加質量要素両端の支持ゴムのばね剛性 $k 1_{j}$ と $k 2_{j}(j=$ $1,2, \cdots, M)$ および減衰係数 $c 1_{j}$ と $c 2_{j}(j=1,2, \cdots, M)$ である。

図 5 の数学モデルと最適化手法を用いて, 各設計変 数を次のアルゴリズムに従って決定する.

ステップ 1. 機能上の要求から,ボーリングバ一の突

出し長さ $L_{t}$ および外径 $D_{1}$ を決定する。

ステップ2. ボーリングバーの内径 $D_{2}$ の大きさと

静コンプライアンス $f_{s}$ の值の関係を評価して, 要求

される $f_{s}$ の值を満たすよらに $D_{2}$ を決定する。

ステップ 3. ボーリングバーの突出し長さ $L_{t}$ と静コ

ンプライアンス $f_{s}$ の大きさを考慮して，モーダルフ

レキシビリティ $f_{i}$ の分割数 (近似的には静コンプラ

イアンス $f_{s}$ の分割数) $N$ を決定し，それより付加質

\section{量の数 $M$ を定める.}

ステップ 4. 無減衰振動系（または比例减衰系）とし てのモデル化のもとで, $N$ 個の固有モードのモーダ ルフレキシビリティ $f_{i j}(j=1,2, \cdots, N)$ が均一化す る(または設定した值になる)ように, 設計変数 $\left(L_{j}\right.$, $\left.k 1_{j}, k 2_{j}(j=1,2, \cdots, M)\right)$ の概略值を求める.

ステップ 5. ダンパ要素を含めたモデル化（非比例減 衰系としてのモデル化) のもとで, リセプタンス周 波数応答の最大負実部の大きさが最小となるよう に, 設計変数 $\left(L_{j}, k 1_{j}, k 2_{j}, c 1_{j}, c 2_{j}(j=1,2, \cdots, M)\right)$ の值を，ステップ 4 で得られた值を初期値として, 最適值探索手法により決定する。このとき $k 1_{j}, k 2_{j}$, $c 1_{j}, c 2_{j}$ は, 使用可能なゴムの特性值をも考慮して 定める。

\section{5. 試 作 例}

4 節の設計法に従って試作した図 4 (a) に示す防振 ボーリングバーの, 加振実験および切削実験の結果を 述べる。ここでは，ボーリングバーの外径 $D_{1}$ が 0.032 $\mathrm{m}(32 \mathrm{~mm})$, 突出し長さ $L_{t}$ が $0.23 \mathrm{~m}(230 \mathrm{~mm})$ の場 合を対象とした。このとき $L_{t} / D_{1} \fallingdotseq 7$ となり, 通常の ボーリングバーでは切削不能と考兄られている加工条 件である。

付加質量要素として, 径 $D_{3}$ が $0.023 \mathrm{~m}(23 \mathrm{~mm})$ で 長さ $L_{1}$ と $L_{2}$ がそれぞれ $0.04 \mathrm{~m}(40 \mathrm{~mm})$ と $0.07 \mathrm{~m}$

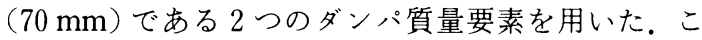
の付加質量要素の材料は, 超重合金 (密度 $1.8 \times 10^{4}$ $\left.\mathrm{kg} / \mathrm{m}^{3}\left(18.0 \mathrm{~g} / \mathrm{cm}^{3}\right)\right)$ である。またアジャストスク リューは, 各要素の組付け時にゴムに一定圧が加わる ように調整するためのもので, 組付け後は固定される.

図 5 (a)の構造解析モデルに対して計算した切削点 Cに拈けるリセプタンス周波数応答の結果を, 図 6 の 実線で示している，比較のために，ダンパ要素を取り 除いたボーリングバーの切削点Cに抢けるリセプタ ンス周波数応答の計算值を破線で示している。この破 線で示される $450 \mathrm{~Hz}$ 付近の大きなリセプタンス值を もつ固有モードが, 実線で示されるように, 5 つの固有 モードに分割されていることがわかる。

これらの計算結果に従って実際に試作した防振ボー リングバーの切削点におけるリセプタンス周波数応答 の測定值を, 図 7 の実線で示している。これは, 旋盤 （大日金属製 $15 \mathrm{P}$ 無段変速旋盤）にボーリングバーを 取り付けた状態で, ハンマによるインパルス加振実験 を行ったものである，比較のために，ダンバ機構をも たない通常の中実のボーリングバー（外径と突出し長 さは防振ボーリングバーと同じ）の，切削点における リセプタンス周波数応答の結果を, 実線で示している.

図 8 の破線は, 防振ボーリングバーによる, 図中に 明記した切削条件のすとでの, 実切削時の加速度信号 (ボーリングバーの先端付近に加速度ピックアップを 取り付けて得たもの)の周波数分析結果を示している. 比較のために, ダンパ機構をもたない通常のボーリン グバーによる同一切削条件時の結果を実線で示す。防 振ボーリングバーでは安定した切削が行われている

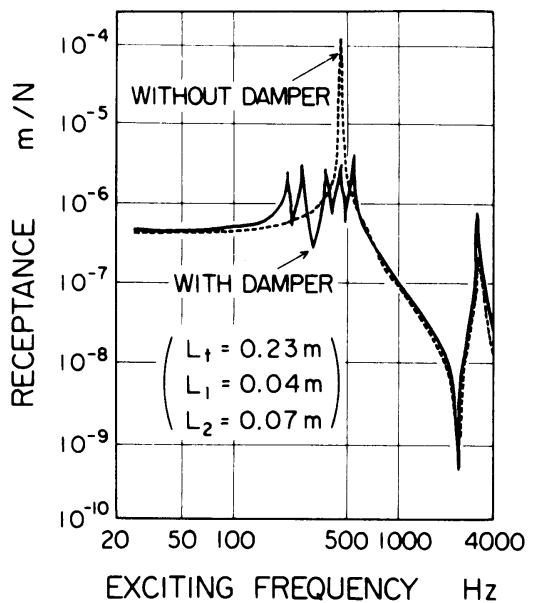

Fig. 6 Computed results of receptance frequency response at the cutting point of the boring bar equipped with two damping mass elements and the boring bar equipped with no damping element 


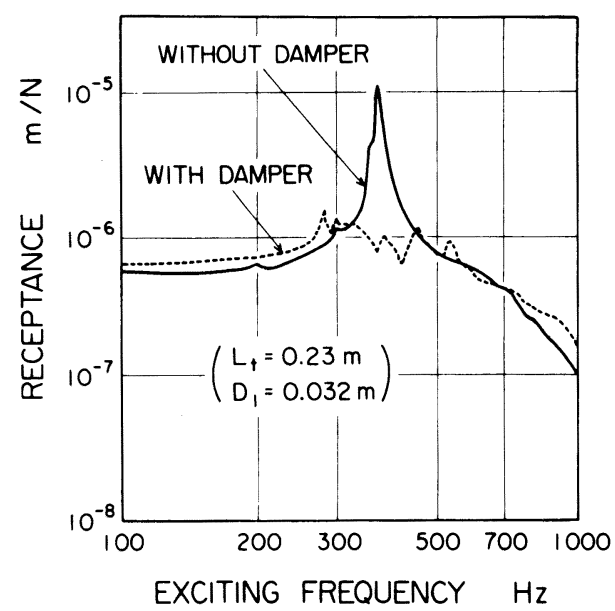

Fig. 7 Measured results of receptance frequency response at the cutting point of the boring bars with damper and without damper

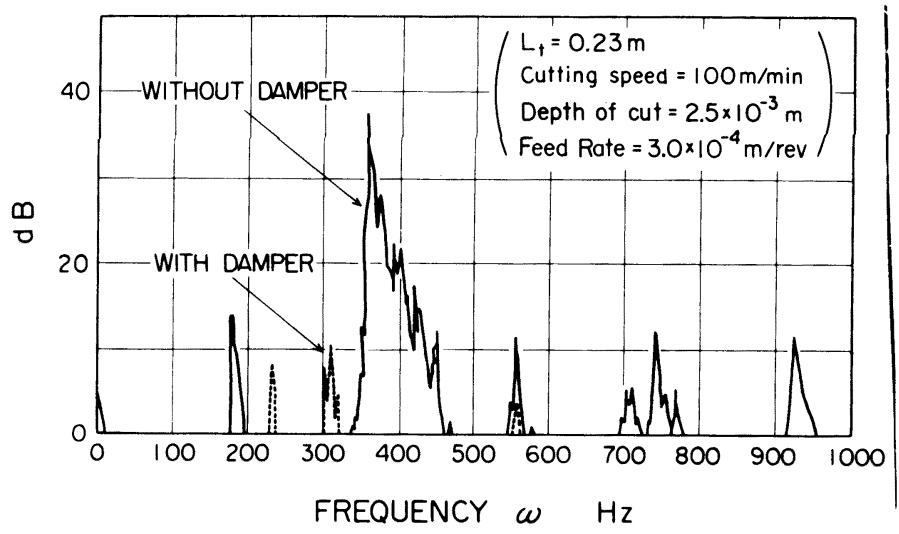

Fig. 8 Results of frequency analyses of accelerometer signals near the cutting point

が，通常のボーリングバーでは大きな振動が発生して いる.

種々の切削条件のもとで, 防振ボーリングバーと通 常のボーリングバーによる切削の情況を比較した結果 を図 9 に示す。これより, 提唱する防振ボーリングバー は, 広い切削条件の範囲で, 良好な切削が可能である ことがわかる.

\section{6. 結 論}

（1）びびり振動の原因となる固有モードのモーダ ルフレキシビリティを, 多くの固有モードのモー ダルフレキシビリティに分割させるダンパ要素を 付加した，防振ボーリングバーを提唱した。

（2）理論的考察の結果, 提唱した防振ボーリング バーは, 最も大きなモーダルフレキシビリティ值 をもつ固有モードのモーダルフレキシビリティの
O: STABLE CUTTING

$\triangle$ : CHATTERING

$x:$ INPOSSIBLE CUTTING

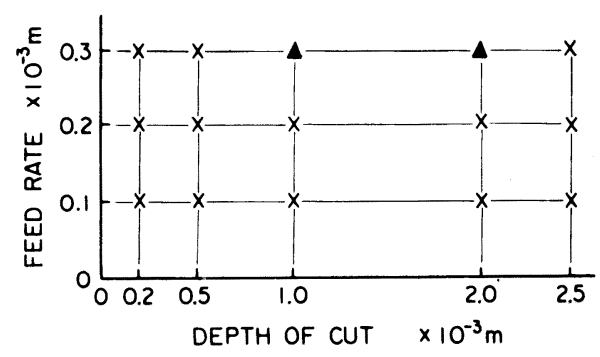

(a) WITHOUT DAMPER

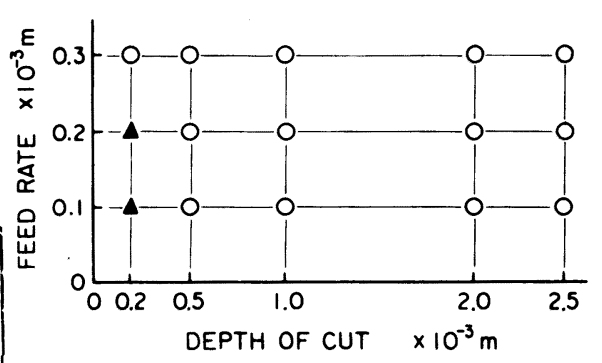

(b) WITH DAMPER ( $\left.L_{1}=0.04 \mathrm{~m}, L_{2}=0.07 \mathrm{~m}\right)$

Fig. 9 States of machining under various cutting conditions

$L_{t}=0.23 \mathrm{~m}$, Cutting speed $; 100 \mathrm{~m} / \mathrm{min}$ 大きさを減少させるばかりでなく，そ の固有モードの減衰比の増大とベクト ル軌跡の正実部方向への移動をもたら すことがわかった。これらのことは, ボーリングバーの再生型自励びびりに 対する安定性を大きく向上させる。

（3）理論的考察に基ついて,防振ボーリ ングバーの設計法を構築した。

（4）試作したボーリングバーの加振実験と切削実 験により，提唱する防振 ボーリングバーの有効 性を確認した。

\section{文献}

1）上野 滋, 森脇俊道, 岩田一明：インパクトダンパを用い たボーリングバーの最適設計に関する研究,精密機械, 46, 12(1980)1481.

2) K. Seto and K. Yamada: An Investigation on Boring Bars Equipped with a Dynamic Absorber, Proc. 4th Int. Conf. Prod. Engg., Tokyo, (1980) 422.

3) F. Koenigsberger and J. Tlusty: Machine Tool Structures, Pergamon Press, (1970) 305.

4）吉村允孝: 工作機械の振動特性に関する最適設計の研究 (工作機械構造物のびびり振動に関する最適化設計), 日本 機械学会論文集，42，363（1976）3428。

5） 3) に同 $i$, p. 297

6）吉村允孝”：機械構造物の振動特性に関する設計感度解析 (周波数応答に打ける感度俰数の解析), 日本機械学会論文 集, 50,449（1984）37.

7）吉村允孝：工作機械の振動特性に関する最適設計一一再 生型自励びびりの最適化を支配する因子の解析, 精密機 械, 43，1（1977） 93. 